\title{
IMPROVING THE STUDENTS' READING COMPREHENSION THROUGH CONCEPT ORIENTED READING INSTRUCTION
}

\author{
Restu Januarty Hamid ${ }^{1}$ \\ Faculty of Teacher Training and Education, Bosowa University, Makassar, Indonesia
}

\begin{abstract}
The objcetive of this research aimed to improve the students reading comprehension at the level of literal and inferential comprehension. This research was a pre-experimental research, which employed one-group pretestposttest. This research was conducted through three steps of process: pre-test, treatment and post-test to investigate the improvement of the student's reading comprehension through the implementation of CORI. Pretest was done to measure the students reading comprehension before conducting the treatment. The treatment, which was the teaching and learning process, was conducted in four meetings in which CORI was applied as method to improve the students reading comprehension. After the treatment, post-test was done to measure the students reading comprehension after the implementation of CORI. Location of this research is the seventh Grade students of SMP Negeri 7 Masamba, at academic year 2015/2016. The total numbers of subjects were 41 students, which were divided into 2 classrooms VII A and VII B. There is two variables of this research; the use of CORI as the independent variable and reading comprehension is the dependent variable. In this research, reading comprehension test was the instruments to collect the data related to the student's reading comprehension at the level of literal and inferential comprehension. The test consisted of multiple choices to assess the student's literal comprehension and essay test to measure the student's inferential comprehension. In testing the hypothesis, $t$-test was employed. The calculation was done by using SPSS v.20. In summary, CORI improved the student's ability to understand and identify the explicitly or directly state the information given in the text; for example, the characters of the story, their traits, place and time where the story taken place, main ideas, details, cause and effect and sequences in the text. Following the improvement of the student's literal comprehension, the student's inferential comprehension was also improved.
\end{abstract}

Keywords:Reading Comprehension, Concept-Oriented Reading Instruction

\section{INTRODUCTION}

The background was developed through instructional principles (social interaction and intrinsic motivations to read such as curiosity, challenge, and 
involvement) for stimulating student's interest and motivation to read (Guthrie, McRae, \& Klauda, 2007).

CORI is guided by instructional principle for stimulating student's interest and motivation to read that has been used and researched extensively in L1 setting (Grabe \& Stoller, 2013).

CORI potentially creates stimulating tasks to pique student's interest and begin a phase of inquiry related to a central concept or theme. In teaching and learning process of CORI, the students are provided opportunities to access a variety of books related to the central concept or theme. Teachers give support, modeling reading strategies, and facilitate student inquiry to enhance student's success in reading comprehension and further motivate students to continue their quest to build upon their newly found information and questions.

In EFL Context especially in Indonesia, the contribution of CORI in increasing both the students intrinsic motivation in reading and reading comprehension had been proven by Swastiko (2012) and Ahriyati (2014). They found that CORI potentially improve the students creativity and reading comprehension

Therefore, CORI is considered as an appropriate method which potentially improve the students reading comprehension at the grade eleventh of SMP Negeri 7 Masamba. Thus, this research was conducted under title, "Improving the Student's Reading Comprehension through Concept-Oriented Reading Instruction". This research was conducted in order to improve the students reading comprehension at the level of literal and inferential comprehension.

\section{REVIEW OF LITERATURE}

Previously, CORI had been implemented in several researchers in order to improve reading comprehension. In the context of teaching reading in Indonesia, there two related research. The first was an experimental research which was conducted by Swastiko (2012), under title, "The Influence of Concept-Oriented Reading Instruction and the Student's Creativity upon Reading Competence". He found that students taught by using CORI have better competence in reading comprehension. The students also have better achievement and creativity after treated through CORI.

The second research was conducted by Ahriyati (2014). She implemented CORI in a classroom action research under title, "Improving the Student's Reading Comprehension through Concept Oriented Reading Instruction Strategy". She found that CORI could improve the student's reading comprehension at the eighth grade student's of SMA Pepabri Makassar. Her research was focused on the student's literal comprehension which covered main idea, sequence detail, and prediction outcomes; and the students' inferential comprehension in term of making conclusion. 


\section{A. Concept-Oriented Reading Instruction (CORI) \\ 1. The Concept of CORI}

CORI is a reading comprehension instructional program that combines skills and strategies, knowledge, motivation, and social collaboration to build more knowledge. It was developed through instructional principles(social interaction and intrinsic motivations to read such as curiosity, challenge, and involvement) for stimulating student's interest and motivation to read (Guthrie, McRae, \& Klauda, 2007).

The social collaboration students experience in school can affect intrinsic motivation, strategy learning and use, and conceptual knowledge either positively or negatively-depending on the quality of the social collaboration (Guthrie, Wigfield, \& You, 2012). In summary, according to the engagement theory, engaged readers are intrinsically motivated, builds knowledge, uses cognitive strategies, and interacts socially to learn from text. The engagement perspective on reading integrates cognitive, motivational, and social aspects of reading.

\section{The Implementation of CORI}

In order to increase both reading comprehension and reading engagement, CORI provides four phases of instructions: observing and personalizing; searching and retrieving; comprehending and integrating; and communicating to other.

These phases of instructions of CORI are described as follow;

\section{a. Observing and Personalizing}

This phase included bringing background experience and knowledge into the learning and exploration processes. The students are encouraged to select a subject important to them and to identify topics (such as moon craters) to which they wanted to devote time and energy in their learning.

In conclusion, this phase employs two strategies of reading comprehension; activating background knowledge and questioning.

\section{b. Searching and Retrieving}

The students are expected to acquired concepts according to their choices, they would be motivated to form increasingly higher order abstractions and generalizations about the themes they are studying. In searching retrieving, the students are allowed choose their own book to use in learning about the subtopics they selected (Guthrie, McRae, \& Klauda, 2007).

\section{c. Comprehending and Integrating}

The comprehending and integrating encompassed the following comprehension strategies: (a) determining the topic of a text selection; (b) detecting critical details; (c) summarizing the text; (d) making comparisons between texts; (e) developing criteria for evaluating a book; and (f) critically reflecting on the author's point of view and presentation of information (Guthrie, McRae, \& Klauda, 2007). According to Anderson (2004), learning takes place when new information is integrated with what is already known. The more prior knowledge and experience readers have with a particular topic, the easier it is for them to make connections between what they are learning and what they know 


\section{d. Communicating to Others}

This phase emphasized the students learn to identify important information, to organize that information into a coherent form, and to express their ideas precisely and convincingly. The students are allowed to decide how to present their knowledge or information they have gained. This phase aims to create a cycle of opportunities for social interaction.

According to Guthrie and Wigfield (2012), engaged learners achieve because they want to understand, they possess intrinsic motivation for interacting with text, they use cognitive skills to understand, and they share knowledge by talking with teacher and peers.

\section{B. Reading Comprehension}

\section{The Concept of Reading Comprehension}

Reading comprehension is an important goal of the reading. It is an activity aimed to understand and interpreting the information of a particular text (Cahyono \& Widiati, 2006). It is about the construction of meaning more than passive remembering. The goal is to gain the overall understanding of what is described in the text rather than to obtain meaning from isolated words or sentences (Woolley, 2011:15).

According to Mikulecky (2008), Reading comprehension is result of interaction between the perception of graphic symbols that represent spoken language and the reader language skill, cognitive skill, and the knowledge of the world.

\section{Skills of Reading Comprehension}

These skills and abilities are divided into levels based on the complexities and difficulties. However, based on the scope of the study, here only described skills of reading comprehension at the level literal and inferential. below:

Both of these levels of skills in reading comprehension are described

\section{a. Literal Comprehension}

The first key to comprehending a written passage is to understand it from a literal point of view. Literal comprehension is seen as the first level of comprehension. It is the simplest form of locating information in texts because it focuses only to the information that is stated directly in the text.

\section{b. Inferential Comprehension}

Inference is another word for conclusion. It is often described simply as the ability to read between the lines. The ability to generate inferences is an essential skill that greatly determines the degree to which a passage will be understood (Green \& Roth, 2013).

According to Cain (2009:856) relevant background knowledge for a passage is a better predictor of fourth graders' ability to generate inferences from and elaborate on that text than is their comprehension skill. It means inferential making depends the readers' ability to make connecting between information within the text and their background knowledge. The relationship between 
background knowledge and inferencing is not reciprocal. Elaborative inferences cannot be drawn without the prerequisite knowledge. However, just because a reader has that background knowledge does not automatically guarantee that the reader will necessarily make the inference.

\section{METHODOLOGY}

This research was a pre-experimental research, which employed one-group pretest-posttest. This research was conducted through three steps of process: pretest, treatment and post-test to investigate the improvement of the student's reading comprehension through the implementation of CORI. Pretest was done to measure the students reading comprehension before conducting the treatment. The treatment, which was the teaching and learning process, was conducted in four meetings in which CORI was applied as method to improve the students reading comprehension. After the treatment, post-test was done to measure the students reading comprehension after the implementation of CORI. Location of this research is the seventh Grade students of SMP Negeri 7 Masamba, at academic year 2015/2016. The total numbers of subjects were 41 students, which were divided into 2 classrooms VII A and VII B. There is two variables of this research; the use of CORI as the independent variable and reading comprehension is the dependent variable. In this research, reading comprehension test was the instruments to collect the data related to the student's reading comprehension at the level of literal and inferential comprehension. The test consisted of multiple choices to assess the student's literal comprehension and essay test to measure the student's inferential comprehension. In testing the hypothesis, t-test was employed. The calculation was done by using SPSS v.20.

\section{FINDINGS AND DISCUSSION}

\section{A. Findings}

\section{The Improvement of the Students Literal Comprehension}

The result of data analysis shows that in pretest, the maximum score was 90 and the minimum score was 40 , while the range was 50. In posttest, the maximum score was 90 and minimum score was 50, while the range was 40 . Based on the data analysis, it was found that the student's literal comprehension improved through CORI. After being calculated, it was found that the mean score of pretest was 58.57, while the mean score of posttest was 69.52. The improvement of the student's literal comprehension is further shown in figure 1: 


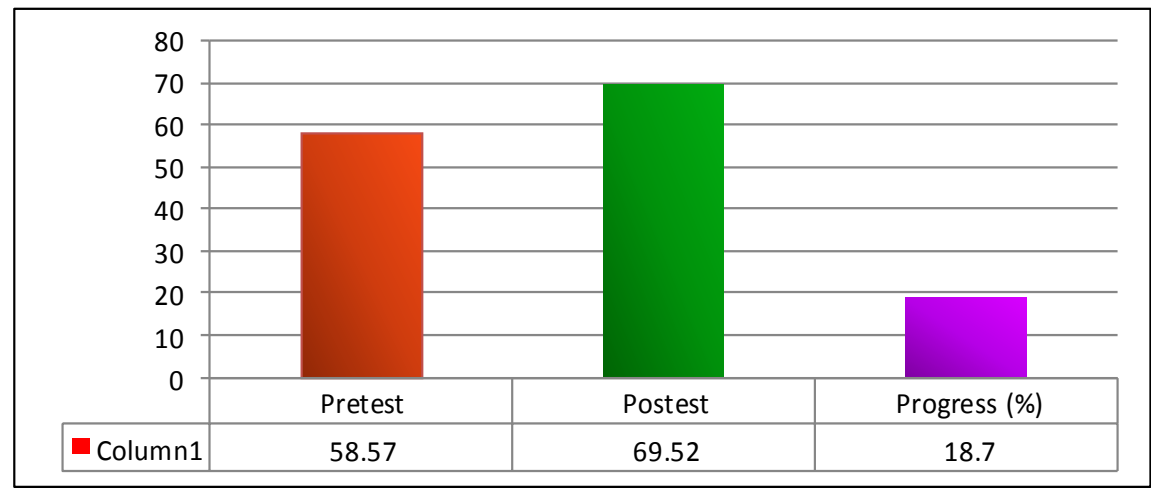

Figure 1. The Improvement of the Student's Literal Comprehension

Figure 1 represents the student's mean score of literal comprehension in both pretest and posttest and its percentage of improvement. The red chart represents the student's mean score of pretest, and the mean score of posttest is represented by the green chart, while the percentage of improvement is represented by the purple chart. Based on the chart above, the student's mean score of posttest was 60, while the mean score of pretest was 70.83. In summary, the mean score of posttest is greater than the pretest $(69.52>58.57)$. The percentage of improvement of the student's mean score was $18.7 \%$. It means, the student's literal comprehension improved through CORI.

\section{The Improvement of the Student's Inferential Comprehension}

The improvement of the student's literal comprehension was followed by the improvement in inferential comprehension. It was found that the student's inferential comprehension was also improved after the treatment. The result of data analysis shows that in pretest, the maximum score was 75 and the minimum score was 40 , while the range was 35 . In posttest, the maximum score was 85 and minimum score was 60 , while the range was 25 . After being calculated and analyzed, the mean score of the student's inferential comprehension of pretest was 55.95, while the mean score of posttest was 69.29. The student's inferential comprehension is shown in figure 2 .

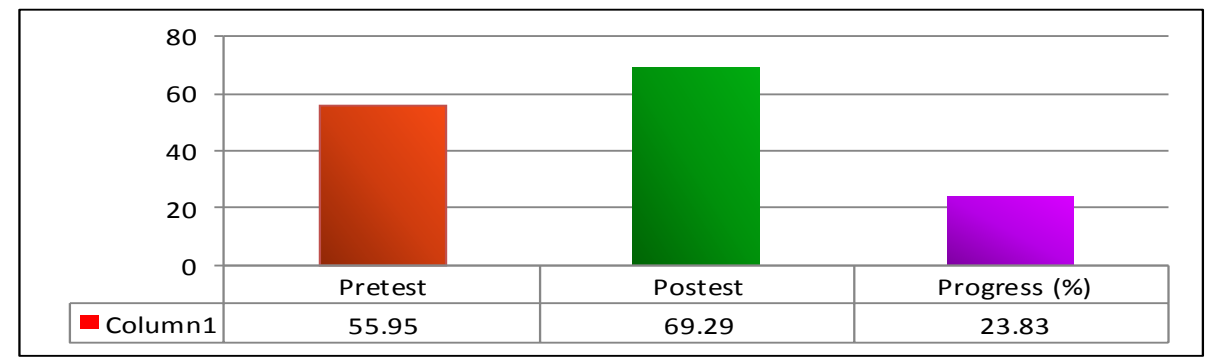

Figure 2. The Improvement of the Student's Inferential Comprehension 
Figure 2 above, represents the mean scores of the students inferential comprehension in both pretest and posttest. The red chart represents the student's mean score of literal comprehension in pretest, while the mean score of posttest which is represented by the green chart and the percentage of improvement is shown in the purple chart. Based on the chart above, the student's mean score of pretest was 55.95, and the mean score of posttest was 69.29 . In other words, the mean score of posttest is greater than the pretest $(55.95>69.29)$, while the percentage of improvement which is shown in chart purple was $23.83 \%$. In conclusion, the student's inferential comprehension improved $23.83 \%$ through CORI.

Since the student's literal and inferential comprehensions improved, it consultable that CORI did improve the student's reading comprehension at the seventh Grade of SMP Negeri 7 Masamba. After being calculated and analyzed, it was summarized that the mean score of the students reading comprehension of pretest was 57.26, the mean score of posttest was 69.40 , while the percentage of improvement was $21.26 \%$, as it presented in the following.

Table 1. The Improvement of the Students Reading Comprehension

\begin{tabular}{|l|l|l|l|}
\hline \multirow{2}{*}{ Variables } & \multicolumn{2}{|l|}{ Mean Score } & \multirow{2}{*}{ Progress (\%) } \\
\cline { 2 - 3 } & Pretest & Posttest & \\
\hline Literal & 58.57 & 69.52 & 18.70 \\
\hline Inferential & 55.95 & 69.29 & 23.83 \\
\hline$\sum$ & 114.52 & 138.81 & 42.53 \\
\hline$X$ & 57.26 & 69.40 & 21.26 \\
\hline
\end{tabular}

Based on the table 1 above, the mean score of the student's literal comprehension in pretest was 58.57 and improved to $69.52 \mathrm{in}$ posttest. the percentage of improvement was $18.7 \%$. The student's inferential comprehension was also improved following the students literal comprehension. The mean score of the student's inferential comprehension of pretest was 55.95, it was improve to 69.29 in posttest, while the percentage of improvement was $23.83 \%$. In summary, the mean score of the students reading comprehension in pretest was 57.26, it improved to 69.4 in posttest, while the percentage of improvement was $21.26 \%$. In other words, the students reading comprehension improved $21.26 \%$ through CORI.

Further, the improvement of the student's reading comprehension is presented in the following chart: 


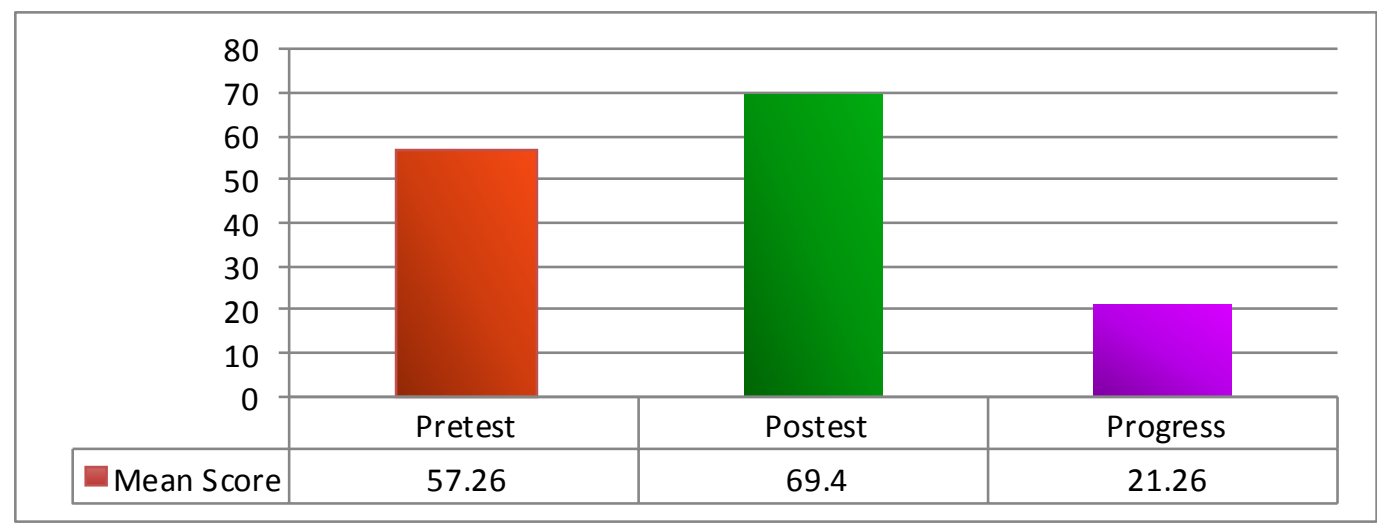

Figure 3. The Improvement of the Student's Reading Comprehension

Figure 3 describes the improvement of the student's reading comprehension. The red chart represents the student's mean score of reading comprehension in pretest, and the mean score of posttest, which is represented by the green chart, while the percentage of improvement is shown in the purple chart. The mean score in posttest is greater than the pretest $(69.4>57.26)$, while the percentage of the improvement was $21.26 \%$. It indicates that the students reading comprehension improved $21.26 \%$ after the treatment. In conclusion, CORI does improve the student's reading comprehension at the seventh Grade of SMP Negeri 7 Masamba.

\section{Test of Significance}

The hypothesis was done through inferential analysis. The $t$ test (test of significance) was employed to find out the significant difference between the student's mean scores in pretest and posttest. Considering the level of significance $(\alpha)=0.05$, and the degree of freedom $(\mathrm{df})$ was $21-1=20$, it was found that $t$ table was 2.086. The result of test of significance is shown on the following table.

Table 2. The Result of t-test

\begin{tabular}{|l|l|l|l|}
\hline Variables & $\mathbf{T}_{\text {test }}$ & $\mathbf{T}_{\text {table }}$ & Remarks \\
\hline Literal & 7.167 & 2.086 & Significantly different \\
\hline Inferential & 6.595 & 2.086 & Significantly different \\
\hline
\end{tabular}

Table 2 above shown that both variables significantly different before and after the treatment through CORI. The result of result of hypothesis testing showed that there is significant difference of the student's literal comprehension in pretest and posttest. It was found that $t_{\text {test }}>t_{\text {table }}(7.167>2.086)$. At the level of inferential comprehension, it was also found that $t_{\text {test }}>t_{\text {table }}(6.595>2.086)$. Considering the criteria of hypothesis testing, the null hypothesis $\left(\mathrm{H}_{0}\right)$ was 
rejected, and alternative hypothesis $\left(\mathrm{H}_{1}\right)$ was accepted. It means the student's comprehension in terms of literal and inferential comprehension improved through CORI. In other words, CORI improved the students reading comprehension in terms literal and inferential comprehension.

\section{B. Discussion}

This research was conducted three steps, based on the design of preexperimental research: pretest, treatment, and posttest. Pretest was conducted in order to measure the student's reading comprehension in terms of literal and inferential comprehension. The second step was treatment; it was process of implementing CORI in teaching and learning process. The treatment was conducted in four meetings. After the treatment, the last step was posttest, it was meant to measure the student's improvement of reading comprehension.

The result of data analysis indicated that the mean score of the student's literal comprehension in pretest was 58.57 while the mean score of the student's inferential comprehension was 55.95. Regarding to the mean score of literal and inferential comprehension in pretest, it was found that the mean score of the students reading comprehension was 57.26. Considering the minimum successful criteria on SMP Negeri 7 Masamba which is $\geq 65,17$ of 21 students of grade VII awere failed in pretest. This result of pretest showed that the students reading comprehension still far from it was expected and need to be improved. The student's weakness in reading comprehension is reasonable regarding to their environment where the students only find English text in their handbooks. Other reason comes from their intrinsic motivation in reading. The English teacher of grade VII A put emphasize on the student's knowledge of sentence structure through direct teaching. This method of teaching makes the students feel bored and are not interested in learning English. Most of them think that English is difficult to understand for it's complicated grammatical rules.

After the pretest, it was recognized that generally the students were failed to recognize the meaning of the words, which indicated that the students were lack of vocabulary mastery, especially in identifying the meaning of verb in past form. Therefore, in answering the multiple choices most students chose the options randomly. The student's weakness on literal comprehension led to their failure on inferential comprehension. However, some of the students were able to understand the questions of the test.

Based on the result of the pretest, the treatment was conducted, in order to minimize the student's weakness in literal and inferential comprehension and to improve their achievement in reading comprehension. During the treatment which was conducted in five meetings, the student's are provided difference text and worksheet each meeting. The materials and worksheet are constructed appropriately following the principle of CORI which put emphasize on increasing the students motivation in reading with interesting reading material and meaningful activities during the lesson. While the students reading comprehension is improved by teaching the students how to extract information of the text. Each 
meeting, the students delivered narrative text in form of fairy tale, urban legends which the students familiar with, and other story which consists of moral education. During the lesson, each student are given worksheets, which are intended to help the students to identify and understand the important information of the given text. Therefore, by the help of the given worksheets and interesting reading material, the students are easily involved in each phase of implementation of CORI.

After four meetings of treatment, the students were given posttests to measure the reading comprehension. the result of posttest shows that the students reading comprehension improved. The mean score of the student's literal comprehension reached to 69.52, while their inferential comprehension improved to 69.29. Considering the result of pretest, the student's literal comprehension improved $18.7 \%$, while their inferential comprehension improved to $23.83 \%$. In other words, the student's reading comprehension improved through of CORI. In summary, the mean score of reading comprehension in posttest (69.40) is greater than the pretest (57.26). It indicates that the students reading comprehension is improved, while the percentage of the improvement was $21.26 \%$.

The result of $t_{\text {test }}$ shows that there is significant difference of the student's literal comprehension between pretest and posttest where $t_{\text {test }}>t_{\text {table }}(7.167$ >2.086). In the level of inferential comprehension, it was also found that $t_{\text {test }}$ > $\mathrm{t}_{\text {table }}(6.595>2.086)$. Regarding to the criteria of hypothesis testing, the null hypothesis $\left(\mathrm{H}_{0}\right)$ is rejected, and alternative hypothesis $\left(\mathrm{H}_{1}\right)$ was accepted. It means the student's literal and inferential comprehension improved through CORI. Considering the minimum successful criteria at SMP Negeri 7 Masamba, which was 65 , it was also shown that the students reading comprehension improved. After being classified into categories, Failed $(x<65)$ and Success $(x \geq 65)$, in pretest 17 students $(80.95 \%)$ were failed, and 4 students $(19.05 \%)$ were success. In posttest, 3 students $(14.29 \%)$ were failed, while 18 students $(85.71 \%)$ were success.

In summary, CORI improved the student's ability to understand and identify the explicitly or directly state the information given in the text; for example, the characters of the story, their traits, place and time where the story taken place, main ideas, details, cause and effect and sequences in the text. Following the improvement of the student's literal comprehension, the student's inferential comprehension was also improved. In the inferential level, the students give better respond to the text given. They are able to infer the information that is not directly-stated in the text. It is evidence that the intrinsic reading motivation highly correlate to the student's reading comprehension. When the students gain conceptual knowledge, they feel more intrinsically motivated to read. The social collaboration students experience in school can affect intrinsic motivation, strategy learning and use, and conceptual knowledge either positively or negatively-depending on the quality of the social collaboration (Guthrie, Wigfield, \& You, 2012). In relation to the previous explanation, it consultable that CORI does improve the student's reading comprehension at the level of literal and 
inferential comprehension at the seventh Grade students of SMP Negeri 7 Masamba.

\section{CONCLUSION}

The conclusion of this research are (1) The students' literal comprehension at the seventh Grade of SMP Negeri 7 Masamba improved. It is indicated by the mean score of pretest, which was58.57, improved to $69.52 \mathrm{in}$ posttest, while the percentage of improvement was $18.70 \%$. The improvement was significant in which $t_{\text {test }}>t_{\text {table }}(7.167>2.086)$, and (2) The students' inferential comprehension at the seventh Grade of SMP Negeri 7 Masamba improved. It is indicated by the mean score of pretest, which is 55.95, its improved to 69.29 in posttest, while the percentage of improvement is $23.83 \%$. The improvement was significant in which $t_{\text {test }}>t_{\text {table }}(6.595>2.086)$.

\section{REFERENCE}

Akhriyati, N. (2014). Improving the Students' Reading Comprehension through Concept-Oriented Reading Instruction (CORI) Strategy (A Classroom Action Research at SMP Dharmawirawan Pepabri Makassar for the Second Grade). Thesis. FKIP Unismuh Makassar.

Cain, K. (2009). Children's Reading Comprehension Difficulties. A Consideration of the Precursors and Consequences. In C. Wood, \& C. Vincent (Eds.), Contemporary Perspectives on Reading and Spelling. New York: Routledge.

Grabe, W., \& Stoller, F. (2013). Teaching and Researching Reading (2 ed.). (C. N. Candlin, \& D. R. Hall, Eds.) New York: Routledge.

Green, L. B., \& Roth, K. L. (2013). Increasing Inferential Reading Comprehension Skills: A Single Case Treatment Study. Canadian Journal of Speech-Language Athology and Audiology, 37(3), 228-239.

Guthrie, J. T., McRae, A., \& Klauda, S. L. (2007). Contributions of ConceptOriented Reading Instruction to Knowledge about Interventions for Motivations in Reading. Educational Psychology, 42(10), 237 - 250.

Guthrie, J. T., Wigfield, A., \& You, W. (2012). Instructional Contexts for Engagement and Achievement in Reading. In S. L. Christenson (Ed.), Handbook of Research on Student Engagement (pp. 601-634). College Park, MD, USA: Springer Science+Business Media.

Mikulecky, B. S. (2008). Teaching Reading in a Second Language. Pearson Education.

Swastika, Y. (2012). The Influence of Concept-Oriented Reading Instruction and the Student's Creativity upon Reading Competence. Retrieved 5 2015, 25, from http://pasca.uns.ac.id/?p=2749.

Woolley, G. (2011). Reading Comprehension: Assisting Children with Learning Difficulties. Springer Science +Business Media B.V. 